\title{
Effect of Increasing Zinc Concentration in the Diets of Brown Parent Stock Layers on Various Production and Hatchability Traits (Short communication)
}

\begin{abstract}
Effect of increasing zinc concentration in the diets of brown parent stock layers on various production and hatchability traits was investigated. After hatching, chicks were allocated to different treatment groups whose diets were formulated to contain graded concentrations 60 (control), 90, 120, 150, 180 and $210 \mathrm{mg}$ zinc (Zn) $\mathrm{kg}^{-1}$ throughout 62 weeks. No effect of increasing zinc concentration on egg production, $5 \%$ egg production age, livability and hatchability rate was found $(\mathrm{P}>0.05)$. On the other hand, significant differences were obtained with increase in zinc concentration in egg weight, feed conversion rate and hatchability effciency of the fertile eggs $(\mathrm{P}<0.05)$. The results of the present study suggest that the diets of brown parent stock layers should include 180 mg Zn kg-1 for optimal performance and hatchability traits.
\end{abstract}

Key Words: zinc, hatchability, fertility, brown layers, feed conversion ratio

\section{Zusammenfassung}

Titel der Arbeit: Einfluss der steigenden Zink-Konzentration im Futter auf einige Produktions- und Brutmerkmale bei einer braunen Legehennen-Elternlinie (Kurzmitteilung)

Der Einfluss der Zink-Konzentrationen im Futter auf einige Produktions- und Brutmerkmale bei braunen Elternlinien wurde untersucht. Nach dem Schlupf sind die Küken in vier Futterrationsgruppen aufgeteilt worden. Die Rationen enthielten jeweils 60 (Kontrollgruppe), 90, 120, 150, 180 und 210 mg Zink pro kg Futter. Der Versuch erstreckte sich auf 62 Wochen. Es wurde kein signifikanter Einfluss der steigenden Zink-Konzentration auf den Legebeginn gefunden ( $\mathrm{P}>0.05)$. Andererseits sind signifikante Unterschiede zwischen den ZinkKonzentrationsgruppen beim Eigewicht, der Futterverwertung und der Schlupfeffizienz beobachtet worden $(\mathrm{P}<0,05)$. Die relativ besten Produktions- und Brutergebnisse wurden bei der Futterration mit $180 \mathrm{mg}$ Zn pro kg festgestellt.

Schlüsselwörter: Zink, Schlupffähigkeit, Fertilität, braune Legehennen, Futterverwertung

1.

Introduction

Zinc is an essential element for animals and has important functions in metabolic activities such as protein synthesis, carbohydrate metabolism, reproduction, enzyme activation and growth (UNDERWOOD and SUTTLE, 1999). Deficiencies of zinc are manifested as retarded growth, loss of appetite, decrease in egg production and reproductive performance, problems in bone and skin development and, mortality (KUTLU et al., 1998).

Zinc requirements are reported to be 40 for 0 -8 week chicks, 35 for 8-18 week chickens, 50 for laying hens and $65 \mathrm{mg} \mathrm{kg}^{-1} \mathrm{DM}$ for parent stocks (UNDERWOOD and SUTTLE, 1999). In addition, broilers and laying hens can tolerate $1-2 \mathrm{~g} \mathrm{~kg}^{-1} \mathrm{DM}$ 
of zinc in their diets, but further increases in zinc concentration (up to $4 \mathrm{~g} \mathrm{~kg}^{-1} \mathrm{DM}$ ) lead to loss of appetite and retarded growth (OH et al., 1979).

The present literature showed that most studies involved the use of zinc supplements for a certain period of time and determined various production traits (PALAFOX and HO-A, 1979; SANFORD, 1979; ELTOHAMY et al., 1980; STAHL et al., 1986, 1990). However, no information exists on the effect of dietary zinc level on growth and laying performance of layers from day 1 to the end of first laying period.

The present study was, therefore, designed to determine optimal zinc concentration for brown parent stock layers. The effect of increasing zinc concentration in the diets of brown parent stock layers on various production and hatchability traits was investigated. The unique feature of this study was that zinc supplemented diets were fed to the animals throughout 62 weeks (from day 1 to 62 weeks).

\section{2.}

\section{Materials and Methods}

Four hundred and eighty (432 female and 48 male) ATE-K (Ankara Poultry Research Institute Brown Laying Hens) brown layers were used from day 1 up to the age of 62 weeks in this study. Birds were divided into 6 different treatment groups, each of which had 4 sub-groups as replicates. Eighteen female and two male birds were kept in a $5.6 \mathrm{~m}^{2}$ of a floor-based system. The lighting during the production period was kept $16 \mathrm{~h}$. The diets and water were offered ad libitium to the animals.

A corn-soybean-basal diet with a $\mathrm{Zn}$ concentration of $60 \mathrm{mg} \mathrm{kg}^{-1} \mathrm{DM}$ was used in the present study. The birds received six different diets of varying nutrient compositions formulated according to animals' physiological stages for 0-6 weeks, 7-12 weeks, 1318 weeks, 18 week - 5\% egg production, $1^{\text {st }}$ production period and $2^{\text {nd }}$ production period. The nutrient compositions of the diets fed to the birds in each period are given in Table 1. Graded concentrations of $\mathrm{Zn}\left(0,30,60,90,120,150 \mathrm{mg} \mathrm{kg}^{-1} \mathrm{DM}\right)$ in the form of $\mathrm{ZnO}$ as an commercial $\mathrm{Zn}$ premix were added to all basal diets for each period, giving final $\mathrm{Zn}$ concentrations of 60, 90, 120, 150, 180, $210 \mathrm{mg} \mathrm{kg}^{-1} \mathrm{DM}$.

\section{Table 1}

Composition of Zn control diets fed to the animals throughout 62 weeks (Futterzusammensetzung während der 62 Versuchswochen)

\begin{tabular}{|c|c|c|c|c|c|c|}
\hline Nutrients & $\begin{array}{l}0-6 \text { week } \\
\text { chick diet }\end{array}$ & $\begin{array}{c}\text { 7-12 week } \\
\text { chicken diet }\end{array}$ & $\begin{array}{l}\text { 13-18 week } \\
\text { chicken diet }\end{array}$ & $\begin{array}{c}18 \text { week - } \\
5 \% \text { egg diet }\end{array}$ & $\begin{array}{l}1^{\text {st }} \text { period } \\
\text { egg diet }\end{array}$ & $\begin{array}{c}2^{\text {nd }} \text { period } \\
\text { egg diet }\end{array}$ \\
\hline Crude protein (\%) & 18.00 & 17.00 & 15.50 & 16.00 & 16.00 & 15.50 \\
\hline Crude fiber (\%) & 5.00 & 6.30 & 6.50 & 5.90 & 5.00 & 5.00 \\
\hline Crude fat (\%) & 5.00 & 5.00 & 5.00 & 5.50 & 5.50 & 5.00 \\
\hline Crude ash (\%) & 5.90 & 5.50 & 5.30 & 9.50 & 12.00 & 12.00 \\
\hline Methionine (\%) & 0.45 & 0.40 & 0.35 & 0.40 & 0.38 & 0.33 \\
\hline Lysine (\%) & 0.95 & 0.85 & 0.75 & 0.80 & 0.80 & 0.77 \\
\hline Ca (\%) & 1.00 & 0.90 & 0.90 & 2.50 & 3.60 & 3.70 \\
\hline Total P (\%) & 0.80 & 0.70 & 0.65 & 0.70 & 0.60 & 0.55 \\
\hline $\mathrm{ME} \mathrm{kcal} / \mathrm{kg}$ & 2850 & 2800 & 2750 & 2750 & 2750 & 2700 \\
\hline Cystein (\%) & 0.35 & 0.33 & 0.30 & 0.30 & 0.30 & 0.25 \\
\hline K (\%) & 0.75 & 0.65 & 0.60 & 0.65 & 0.70 & 0.70 \\
\hline Linoleic acid (\%) & 1.80 & 1.80 & 1.80 & 2.00 & 2.10 & 2.00 \\
\hline Triptophan (\%) & 0.20 & 0.18 & 0.16 & 0.17 & 0.17 & 0.17 \\
\hline $\mathrm{Na}(\%)$ & 0.15 & 0.15 & 0.15 & 0.15 & 0.15 & 0.15 \\
\hline Available P (\%) & 0.45 & 0.40 & 0.35 & 0.42 & 0.35 & 0.30 \\
\hline Threonine (\%) & 0.70 & 0.65 & 0.62 & 0.68 & 0.68 & 0.65 \\
\hline Zinc $\mathrm{mg} \mathrm{kg}^{-1} \mathrm{DM}$ & 60 & 60 & 60 & 60 & 60 & 60 \\
\hline
\end{tabular}


Age of sexual maturity was determined as the time point when the birds reached $5 \%$ of their hen-day egg production. Feed conversion ratio was described as the amount of feed (kg/week) consumed for one kg of eggs ( $\mathrm{kg} /$ week) produced by the same animals. Egg production was determined on daily-basis as the number of eggs laid by the birds. Egg weight was determined simply by weighing twice a week during the trial. Fertility rate was described as the number of fertile eggs to the number of eggs placed in the incubator. Hatchability of fertile eggs was found via a similar way in which the number of live chicks was divided by the number of fertile eggs kept in the incubator. Hatchability efficiency was calculated from the number of live chicks divided by the number of eggs placed in the incubator. Viability was determined by subtracting the number of dead animals from the total number of animals during 62 week period. $\mathrm{Zn}$ analysis in all feed samples was carried out according the method described by AOAC (1990).

The comparison of treatment groups was carried out by Variance Analysis Method using SPSS Statistical Programme 6.1. MSTAT was used to determine the difference between the treatment groups.

\section{Results}

Means for some egg production traits of all the zinc treatment groups are presented in Table 2. Inclusion of graded concentrations of zinc in the diets of brown layers had no significant effect on egg production $(\mathrm{P}>0.05)$ although animals which received 120 , 180 and $210 \mathrm{mg} \mathrm{Zn} \mathrm{kg}^{-1} \mathrm{DM}$ in their diets laid 1.21, 1.64 and 1.76\% more eggs than those of the control group receiving $60 \mathrm{mg} \mathrm{Zn} \mathrm{kg}^{-1} \mathrm{DM}$. The weight of eggs obtained from $120 \mathrm{mg} \mathrm{Zn} \mathrm{kg}^{-1} \mathrm{DM}$ receiving group was higher $(\mathrm{P}>0.05)$ than that of the eggs from 90 and $150 \mathrm{mg} \mathrm{Zn} \mathrm{kg}^{-1} \mathrm{DM}$ receiving groups, but not from other groups $(\mathrm{P}<0.05)$. Feed conversion ratio of 120 and $180 \mathrm{mg} \mathrm{Zn} \mathrm{kg}^{-1} \mathrm{DM}$ receiving groups was lower than that of other treatment groups, indicating better utilization of the feed for egg production. However, the $\mathrm{Zn}$ concentration of $210 \mathrm{mg} \mathrm{kg}^{-1} \mathrm{DM}$ did not provide similar improvement in feed conversion ration as did 120 and $180 \mathrm{mg} \mathrm{Zn} \mathrm{kg}^{-1} \mathrm{DM}$ treatments. The animals reached $5 \%$ of their egg production at about 150 days of age and the values for $5 \%$ egg production age of all the zinc treatments did not differ significantly from that of the control group. Although viability results of the addition groups were numerically higher than that of the control group, these differences were not statistically significant (Table 2).

Table 2

Effect of increasing $\mathrm{Zn}$ concentration in the diets of brown parent stock layers on various production traits (Einfluss der steigenden Zn-Konzentration im Futter auf einige Produktionsmerkmale bei Braunen Legehennen Elternlinien)

\begin{tabular}{c|c|c|c|c|c}
\hline $\begin{array}{c}\text { Zinc } \\
\begin{array}{c}\text { concentration } \\
\left(\mathrm{mg} \mathrm{kg}^{-1} \mathrm{DM}\right)\end{array}\end{array}$ & $\begin{array}{c}\text { Hen-Day Egg } \\
\text { Production (\%) }\end{array}$ & Egg Weight (g) & $\begin{array}{c}\text { Feed } \\
\text { Conversion } \\
\text { Ratio }\end{array}$ & Viability (\%) & $\begin{array}{c}\text { 5\% Production } \\
\text { Age (day) }\end{array}$ \\
\hline 60 & 79.22 & $57.80^{\mathrm{ab}}$ & $2.53^{\mathrm{a}}$ & 92.50 & 149.4 \\
\hline 90 & 79.07 & $57.11^{\mathrm{b}}$ & $2.53^{\mathrm{a}}$ & 95.00 & 147.2 \\
\hline 120 & 80.43 & $58.32^{\mathrm{a}}$ & $2.45^{\mathrm{b}}$ & 97.50 & 146.2 \\
\hline 150 & 78.62 & $56.89^{\mathrm{b}}$ & $2.52^{\mathrm{a}}$ & 93.75 & 146.2 \\
\hline 180 & 80.86 & $57.56^{\mathrm{ab}}$ & $2.48^{\mathrm{ab}}$ & 95.00 & 147.0 \\
\hline 210 & 80.98 & $57.45^{\mathrm{ab}}$ & $2.54^{\mathrm{a}}$ & 97.50 & 148.2 \\
\hline
\end{tabular}

${ }^{\mathrm{a}, \mathrm{b}}$ Columns that do not share the same letters differ significantly $(\mathrm{P}<0.05)$ 
Means for hatchability traits of the treatment groups are presented in Table 3. Hatchability and fertility rate did not differ between different treatment groups $(\mathrm{P}>0.05)$. On the other hand, significant differences were found in hatchability efficiency among different treatment groups $(\mathrm{P}<0.05)$. The greatest hatchability efficiency was observed in $180 \mathrm{mg} \mathrm{Zn} \mathrm{kg}^{-1} \mathrm{DM}$ receiving group and was $1.67 \%$ higher than the control group.

Table 3

Effect of increasing $\mathrm{Zn}$ concentration in the diets of brown parent stock layers on various hatchability traits (Einfluss der steigenden Zn-Konzentration im Futter auf einige Brutmerkmale bei Braunen Legehennen Elternlinien)

\begin{tabular}{c|c|c|c|c}
\hline $\begin{array}{c}\text { Zinc concentration } \\
\left(\mathrm{mg} \mathrm{kg}^{-1} \mathrm{DM}\right)\end{array}$ & Hatchability (\%) & Fertility (\%) & $\begin{array}{c}\text { Hatchability } \\
\text { Efficiency (\%) }\end{array}$ & $\begin{array}{c}\text { Embryo Mortality } \\
(\%)\end{array}$ \\
\hline 60 & 89.33 & 93.66 & $95.33^{\mathrm{bc}}$ & 2.48 \\
\hline 90 & 87.33 & 91.33 & $95.66^{\mathrm{bc}}$ & 1.77 \\
\hline 120 & 89.00 & 94.00 & $94.66^{\mathrm{c}}$ & 1.73 \\
\hline 150 & 89.00 & 93.00 & $95.33 \mathrm{~b}^{\mathrm{c}}$ & 1.27 \\
\hline 180 & 89.00 & 92.33 & $97.00^{\mathrm{a}}$ & 1.21 \\
\hline 210 & 89.33 & 92.66 & $96.33^{\mathrm{ab}}$ & 1.26 \\
\hline
\end{tabular}

${ }^{\mathrm{b}, \mathrm{c} C}$ Columns that do not share the same letters differ significantly $(\mathrm{P}<0.05)$

No significant difference was found among the treatments in embryo mortality $(\mathrm{P}>0.05)$, but embryo mortality declined as the concentration of $\mathrm{Zn}$ increased from 60 to $180 \mathrm{mg} \mathrm{Zn} \mathrm{kg}^{-1} \mathrm{DM}$ in the diet in a concentration-dependent manner (Table 3).

\section{4.}

\section{Discussion}

The present study was undertaken to determine the effect of increasing zinc concentration in the diets of brown parent stock layers on various production and hatchability traits. That zinc supplemented diets were fed to the animals throughout 62 weeks (from day 1 to 62 weeks) provided not only a unique feature to the present study among other similar studies but also important implications for determining the optimal concentration of $\mathrm{Zn}$ in the nutrition of brown parent stock layers.

The results of the present study indicated that the egg production values were not affected by increasing Zn concentration in the diets of the brown parent stock layers. This is an expected finding since the requirements for $\mathrm{Zn}$ of birds are reported as 40 for 0-8 week old chicks, 35 for 8-18 week old chickens, 50 for lying hens and $65 \mathrm{mg}$ $\mathrm{kg}^{-1} \mathrm{DM}$ for parent hens (UNDERWOOD and SUTTLE, 1999). The animals probably received enough amount of $\mathrm{Zn}$ throughout 62 weeks even in the control group (60 $\mathrm{mg}$ $\mathrm{Zn} \mathrm{kg}^{-1} \mathrm{DM}$ ). Several studies also reported no effect of $\mathrm{Zn}$ addition on egg production (HOLDER and HUNTLY, 1978; STAHL et al., 1986; KIDD et al., 1992). However, PAULICKS and KIRCHGESSNER (1994) found a positive effect of Zn supplementation on egg production of lying hens. The response of the animals in the study of PAULICKS and KIRCHGESSNER (1994) to Zn supplementation could be due to the concentration of $\mathrm{Zn}$ in the diet, $20 \mathrm{mg} \mathrm{kg}^{-1} \mathrm{DM}$, which was quite lower than $50 \mathrm{mg} \mathrm{kg}{ }^{-1} \mathrm{DM}$ of $\mathrm{Zn}$ concentration, which is recommended for lying hens (UNDERWOOD and SUTTLE, 1999).

The response of the animals in different treatment groups to $\mathrm{Zn}$ concentration increase in their diets was found variable in terms of mean egg weight. The mean egg weight of 
birds consuming $120 \mathrm{mg} \mathrm{Zn} \mathrm{kg}{ }^{-1} \mathrm{DM}$ was higher than that of other groups (Table 2). The data suggest that the increase in egg weight might not directly be attributable to the increase in $\mathrm{Zn}$ concentration in the diet. Other factors might possibly be involved in this variation in egg weight. In a study by KIDD et al. (1992) with broiler parent stock, no effect of increasing Zn concentration on egg weight was found. The study involved the feeding of 41 week old animals with $\mathrm{Zn}$ for 22 weeks. It is probable that the animals might not have enough time to respond to Zn supplementation in the study of KIDD et al. (1992). In the case of the present study, however, the birds started receiving $\mathrm{Zn}$ supplementation as soon as they came out after hatching and might have responded well to Zn supplementation.

There were significant differences in feed conversion ratio values of the treatments in the present study. The lowest feed conversion ration was obtained in 120 and $180 \mathrm{mg}$ $\mathrm{Zn} \mathrm{kg}^{-1} \mathrm{DM}$ receiving groups, indicating that the birds in these two treatments utilized feed more efficiently than those in other treatments for egg production. However, the birds receiving $210 \mathrm{mg} \mathrm{Zn} \mathrm{kg}^{-1} \mathrm{DM}$ in their diets did not show similar improvement in feed conversion ratio as did those of 120 and $180 \mathrm{mg} \mathrm{Zn} \mathrm{kg}^{-1} \mathrm{DM}$ treatments. This suggests that efficient utilization of nutrients by the brown parent stock layers is probable within a certain range of $\mathrm{Zn}$ concentration, and implies that $\mathrm{Zn}$ concentration higher than $200 \mathrm{mg} \mathrm{kg}^{-1} \mathrm{DM}$ might have adverse effects on the metabolic functions of these animals. The effects of $\mathrm{Zn}$ concentrations which are higher than the $210 \mathrm{mg} \mathrm{kg}^{-1}$ DM tested in the present study on feed conversion ratio, therefore, deserve further investigation by the researches. STAHL et al. (1986) reported no effect of zinc supplementation on feed conversion ratio in Single-comb White Leghorn hens. In that study, twenty four week old hens were supplemented with 10, 20 and $40 \mathrm{mg} \mathrm{kg}^{-1} \mathrm{DM}$ in addition to $28 \mathrm{mg} \mathrm{kg}^{-1} \mathrm{DM}$ in their basal diet. It is quite possible that the concentration of $\mathrm{Zn}$ in the diet, even at the highest concentration (68 $\mathrm{mg} \mathrm{kg}^{-1} \mathrm{DM}$ ) was not high enough to be able to cause any improvement in feed conversion ratio.

Hatchability, fertility rate and hatchability efficiency were also determined in the present study. Hatchability and fertility rate were not influenced by the inclusion of graded concentrations of $\mathrm{Zn}$ in the diets. However, hatchability efficiency was affected by the treatments, the highest hatchability efficiency being with $180 \mathrm{mg} \mathrm{Zn} \mathrm{kg}{ }^{-1} \mathrm{DM}$ receiving group. The results of this study are different from those of PALAFOX and HO-A (1979, 1980), who found that provision of 20,000 mg Zn kg-1 DM resulted in decreases in hatchability and fertility of laying pullets and hens of Single Comb White Leghorn (Hy-Line). However, it must be pointed out here that the Zn concentration which was used by PALAFOX and HO-A $(1979,1980)$ was much greater than the highest $\mathrm{Zn}$ concentration used in the present study, and affected hatchability and fertility performance of the animals negatively. It is also known that broilers or layer hens show tolerance to $\mathrm{Zn}$ at $1,000-2,000 \mathrm{mg} \mathrm{kg}^{-1} \mathrm{DM}$ and slight growth and appetite depression at 4,000 $\mathrm{mg} \mathrm{kg}^{-1} \mathrm{DM}(\mathrm{OH}$ et al., 1979). High dietary concentrations of $\mathrm{Zn}$ would obviously have serious health and performance consequences including hatchability and fertility for chicks and birds. DEWAR et al. (1983), for example, investigating the effects of high dietary concentrations of $\mathrm{Zn}$ demonstrated that chicks given 2,000, 4,000 or 6,000 mg Zn kg-1 DM in their diet from 2 to 6 weeks of age grew poorly, many showing gizzard erosion and lesions of the exocrine pancreas. They also found similar lesions of the gizzard and pancreas in hens after the birds had received 10,000 or $20,000 \mathrm{mg} \mathrm{Zn} \mathrm{kg}^{-1} \mathrm{DM}$ diet for only $4 \mathrm{~d}$. STAHL et al. (1986; 
1990) and KIDD et al. (1993) on the other hand reported that zinc supplementation had no negative effect on hatchability traits.

Although embryo mortality did not statistically different among the Zn concentration treatments, it declined as the concentration of Zn increased from 60 to $180 \mathrm{mg} \mathrm{Zn} \mathrm{kg}{ }^{-1}$ $\mathrm{DM}$ in the diet diet in a concentration-dependent manner (Table 3). When hatchability traits are concerned, it can be suggested that a $\mathrm{Zn}$ concentration of $180 \mathrm{mg} \mathrm{Zn} \mathrm{kg}^{-1} \mathrm{DM}$ in the diet is required to obtain optimal hatchability performance in brown parent stock layers.

The type of diet is a crucial factor in meeting the $\mathrm{Zn}$ requirements of poultry (UNDERWOOD and SUTTLE, 1999). Cereal-based diets including plant sources such as soybean or cotton-seen meal can not deliver enough amount of $\mathrm{Zn}$ to the animals due to the "chelating" effects of phytate (ZEIGLER et al., 1961). It is probable that the use of a corn-soybean-basal diet for the feeding of the birds in the present study increased the demand for $\mathrm{Zn}$. This factor alone may cause differences among different studies reported in the literature.

In conclusion, the results of the present study suggest that the requirements for zinc of brown parent stock layers are higher than suggested $\mathrm{Zn}$ concentration, $65 \mathrm{mg} \mathrm{Zn} \mathrm{kg}{ }^{-1}$ DM for parent hens (UNDERWOOD and SUTTLE, 1999). When various production and hatchability traits are considered together, the diets of brown parent stock layers should include $180 \mathrm{mg} \mathrm{Zn} \mathrm{kg}{ }^{-1} \mathrm{DM}$ zinc for optimal performance.

\section{Acknowledgements}

This study was supported by the Ministry of Agriculture, Turkey (TAGEMHAYSUD-00-13-03-27).

\section{References}

ASSOCIATION OF OFFICIAL ANALYTICAL CHEMISTS.:

Official methods for analysis of the Association of Official Analytical Chemists, $15^{\text {th }}$ edition. Association of Offical Analytical Chemists, Washington, DC, (1990)

DEWAR, W.A.; WIGHT, P.A.; PEARSON, R.A.; GENTLE, M.J.:

Toxic effects of high concentrations of zinc oxide in the diet of the chick and laying hen. British Poultry Science, 24, (1983), 397-404

ELTOHAMY, M.M.; TAKAHARA, H.; OKAMOTO, M.:

Effects of zinc on intact and casrated cockerels. British Poultry Science. 21, (1980), 363-369

HOLDER, D.P.; HUNTLY, D.M.:

Influence of added manganese, magnesium, zinc and calcium level on egg shell quality. Poulty Science, 57, (1978), 1629-1634

KIDD, M.T.; ANTHONY, N.B.; JOHNSON, Z.; LEE, S.R.:

Effect of zinc-methionine supplementation on the performance of mature broiler breeders. Applied Poultry Science, 1, (1992), 207-211

KIDD, M.T.; ANTHONY, N.B.; NEWBERRY, L.A.; LEE, S.R.:

Effect of supplemental zinc in either a corn-soybean or a milo and corn-soybean meal diet on the performance of young broiler breeders and their progeny. Poultry Science, 72, (1993), 1492-1499

KUTLU, H.R.; GÖRGÜLÜ, M.; BAYKAL, L.:

Rasyon çinko düzeyinin etlik piliçlerin büyüme performansı üzerine etkisi (Effect of dietary zinc concentration on growth performance of broilers). I. National Zinc Congress, 12-16 May, Eskişehir/Turkey, (1998), 671-676

OH, S.H.; NAKANE, H.; DEAGAN, J.T.; WHANGER, P.D.; ARSCOTT, G.H.:

Accumulation and depletion of zinc in chick tissue and metallothioneins. Journal of Nutrition, 109, (1979), 1720-1729

PALAFOX, A.L.; HO-A, E.:

Zinc toxicity, egg hatchability, composition and production. Poultry Science, 58, (1979), 1091

PALAFOX, A.L.; HO-A, E.: 
Effect of zinc toxicity in laying white leghorn pullets and hens. Poult Science, 59, (1980), 2024-8

PAULICKS, B.R.; KIRCHGESSNER, M.:

Influence of supply on feed intake and performance of layers. Archiv für Geflügelkunde, 58 (1994), 186-191

SANFORD, P.E.:

Performance of caged egg strain layers fed various levels of zinc-methionine supplements. Poultry Science, 58, (1979), 1103

SPSS.:

SPSS Prefessional Statistics 6.1, USA, (1994)

STAHL, J.L.; COOK, M.E.; SUNDE,M,L.:

Zinc supplementation: Its effect on egg production, feed conversion, fertility and hatchability. Poultry Science, 65, (1986), 2104-2109

STAHL, J.L.; GREGER, J.L.; COOK, M.E.:

Breeding hen and progeny performance when hens are fed excessive dietary zinc. Poultry Science, 69, (1990), 259-263

UNDERWOOD, E.J.; SUTTLE, N.F.:

The mineral nutrition of livestock ( ${ }^{\text {rd }}$ Edition), CABI Publishing, Wallingford, Oxon, UK, (1999), pages, 497

ZEIGLER, T.R.; LEACH, R.M. Jr.; NORRIS, L.C.; SCOTT, M.L.:

Zinc requirement of the chick: factors affecting requirement. Poultry Science, 40, (1961), 1584-1593

Received: 2004-03-04

Accepted: 2004-08-10

Authors addresses

ISMAIL DURMUS, CENGIZHAN MIZRAK, SUEDA ERTAS, MUHAMMET KAYA

Tavukçuluk Araştırma Enstitüsü

PK 47 Ankara/Türkei

Assistant Prof. Dr. CENGIZ ATASOGLU (Corresponding Author)

Canakkale Onsekiz Mart Universitesi,

Ziraat Fakültesi,

Zootekni Bölümü,

17020 Çanakkale/Turkei

E-mail: catasoglu@comu.edu.tr 